Abstracta Iranica

Revue bibliographique pour le domaine irano-aryen

Volume 37-38-39 | 2018

Comptes rendus des publications de 2014-2016

\title{
Lucian N. Leustean (ed.). Eastern Christianity and Politics in the Twenty-First Century
}

Florence Jullien

\section{(2) OpenEdition}

1 Journals

\section{Édition électronique}

URL : http://journals.openedition.org/abstractairanica/45181

DOI : 10.4000/abstractairanica.45181

ISBN : 1961-960X

ISSN : 1961-960X

Éditeur :

CNRS (UMR 7528 Mondes iraniens et indiens), Éditions de l'IFRI

Référence électronique

Florence Jullien, «Lucian N. Leustean (ed.). Eastern Christianity and Politics in the Twenty-First Century», Abstracta Iranica [En ligne], Volume 37-38-39 | 2018, document 34, mis en ligne le 30 décembre 2018, consulté le 26 septembre 2020. URL : http://journals.openedition.org/abstractairanica/45181 ; DOI : https://doi.org/10.4000/abstractairanica.45181

Ce document a été généré automatiquement le 26 septembre 2020

Tous droits réservés 


\title{
Lucian N. Leustean (ed.). Eastern Christianity and Politics in the Twenty- First Century
}

\author{
Florence Jullien
}

\section{RÉFÉRENCE}

Lucian N. Leustean (ed.). Eastern Christianity and Politics in the Twenty-First Century. London, New York: Routledge, 2014, 832 p. ISBN 9781138079465, (Routledge

Contemporary Russia and Eastern Europe 54)

1 Ce panorama des relations entre les États et les différentes Églises chrétiennes chalcédoniennes et non-chalcédoniennes du Moyen-Orient et d'Asie, d'Europe, d'Afrique, d'Amérique et d'Australie, s'étend sur une chronologie assez brève depuis la fin de la Guerre froide jusqu'à nos jours. L'éditeur adopte un classement par choix christologiques. La deuxième partie présente les Églises arménienne apostolique, éthiopienne et érythréenne orthodoxes, copte orthodoxe, syriaque orthodoxe, syriaques d'Inde. La troisième est entièrement dévolue à l'Église apostolique assyrienne catholique de l'Orient (E. Hunter, "The Holy Apostolic Catholic Assyrian Church of the East ", p. 601-620). Une dernière partie aborde certains sujets d'actualité comme le rapport des Églises à la démocratie, les relations entre les Églises orthodoxes, catholiques et grecques, l'éducation religieuse et la vie monastique, ou l'impact des mouvements migratoires, de la sécularisation et de la mondialisation sur les christianismes orientaux au XXIe siècle. 


\section{AUTEURS}

\section{FLORENCE JULLIEN}

CNRS, Mondes iranien et indien, Paris 